\title{
Designing Educational Game of Indonesian Traditional Musical Instruments Based on Android Using Unity 3D
}

\author{
Ahmad Fashiha Hastawan ${ }^{1}$, Putri Khoirin Nashiroh ${ }^{2}$,Agung Adi Firdaus ${ }^{3}$,Hanrian Rossa ${ }^{4}$ \\ Departement of Electrical Engineering, Universitas Negeri Semarang, Semarang, Indonesia ${ }^{1234}$ \\ Ahmad.fashiha@mail.unnes.ac.id ${ }^{1}$,putrikhoirin@mail.unnes.ac.id ${ }^{2}$, agungfirdaus119@ gmail.com $^{3}$, \\ hanrianrossa@students.unnes.ac.id ${ }^{4}$
}

Keywords: Educational Game, Indonesian Traditional Musical Instruments,Android, Unity 3D

Abstract: $\quad$ Nowadays the knowledge of traditional Indonesian musical instruments is deficient. This happens because traditional musical instruments are rarely played and traditional musical instruments are increasingly scarce. Learning multimedia applications Indonesian traditional musical instruments are made to preserve and facilitate learning Indonesian traditional musical instruments. The application was developed based on Android using C\# language and Unity 3D game engine. The system development method that is done is waterfall model. The steps are taken requirements analysis, design, coding, system testing, maintenance. Based on the system testing that has been done, the game functional and sound can work well with $100 \%$ success. The application for introducing traditional Indonesian musical instruments can also make it easier for teachers in schools to introduce traditional Indonesian musical instruments.

\section{INTRODUCTION}

Along with the times, concern for the preservation of Indonesia's national culture, especially traditional musical instruments, is very deficient. Most people prefer modern music than traditional music because modern musical instruments are very easy to find in anywhere such as restaurants, cafes, supermarkets, and in other public places (Rahim, 2016). Really different from traditional musical instruments that are classified as rare. People who want to introduce or want to get to know and learn traditional musical instruments still find it difficult to find traditional musical instruments that are sought. This is because the place of the traditional musical instrument is located quite far away, the price is quite expensive, and so forth. Traditional musical instruments usually can only be found in performances of traditional cultural music or places where there are performances of traditional musical instruments and that too is very rare (Ginting and Sofyan, 2017).

Deficiency of recognition and socialization of Indonesia's own culture in the community is one important factor why people's interest traditional musical instruments is poorly. The introduction of musical instruments is very important given to the community especially for childrenbecause this activity is a way to introduce Indonesian culture early on.
Many media that can be used to introduce traditional musical instruments, one of them through technological advancements. Technological advancements have brought many influence to society, one of which is the trendin the communitywas smartphones or mobile devices. Digital marketing research institute (Emarketer) estimates that in 2018 there will be more than 100 million active smartphone users in Indonesia. With such a large number, Indonesia will become the country with the fourth largest active smartphone user in the world after China, India, and America('Kementerian Komunikasi dan Informatika', 2015). Mobile technologies such as mobile phones and tablets are very interactive and interesting tools in conveying information. There are several advantages of educational games. Games are very useful to improve the logic and understanding of players about a problemthat will improve memory. Besides the advantages of a smartphone that is lightweight, fast, easier to use, and carried while traveling (practical).

Based on the description above, smartphones have the potential to be very good as a learning medium. The advantage of games as interactive learning multimedia is that the use of games emphasizes the activeness and experience of the user so that it can improve student's understanding of the subject matter because the material representation 
through multimedia learning is visual $(\mathrm{Br}$ and Ompusunggu, 2016).Computer Technology Research (CRT) states that people are only able to remember $20 \%$ of what was seen and $30 \%$ of what was heard. However, according to (Widiastuti and Setiawan, 2012) people remember $50 \%$ of what is seen and heard and $80 \%$ of what is seen, heard and done at once. Therefore, the use of games based multimedia as a learning medium is suitable, especially for children. The use of games also sharpens the power of thought and logic that can introduce material to be more interesting to be accepted and understood(Dian Wahyu Putra, A. Prasita Nugroho, 2014).

\section{LITERATURE}

\subsection{Traditional Musical Instruments}

Indonesia has a lot of culture, one of which is a traditional musical instrument. A musical instrument is an instrument that is created or modified with the aim of producing sounds or sounds that produce a rhythm(Dian Wahyu Putra, A. Prasita Nugroho, 2014). Every region in Indonesia must have a traditional musical instrument. One of the uses of traditional musical instruments in addition to entertaining can also be used for traditional ceremonial purposes. Examples of proud and wellknown traditional Indonesian musical instruments are Angklung from West Java and Sasando from Nusa Tenggara.

Along with the times, concern for the preservation of national culture, especially traditional musical instruments, is verydeficient. Traditional musical instruments have become very rare, especially in urban settings(Dian Wahyu Putra, A. Prasita Nugroho, 2014). Traditional musical instruments are a cultural heritage that we must maintain and we will inherit back to our children and grandchildren as the next generation of the nation. Lack of recognition and socialization of Indonesia's own culture in the community is one important factor why people's interest is lacking in traditional musical instruments.

\subsection{Educational Games}

Games can be used to support learning and teaching through educational games. Games have positive functions and benefits for children including problem-solving and logic exercises, training motor nerves and spatial skills, establishing children's communication with parents while playing together, and providing entertainment. In fact, for certain patients, gameplay can be used as a healing therapy(Dian Wahyu Putra, A. Prasita Nugroho, 2014).

Based on(Vitianingsih, 2016), there are several advantages of educational games compared to conventional educational methods. One of the main advantages of educational games is the visualization of real problems, so as to improve memory. Besides games also make learning more varied and not boring.

\subsection{Android Smartphone}

Android is an operating system for Linux-based mobile device that includes an operating system, middleware, and applications. Android provides an open platform for developers to create their applications. Android is an operating system on more than one billion smartphones and tablets(Dian Wahyu Putra, A. Prasita Nugroho, 2014). Heriyanto(Rahim, 2016)revealed Android users in Indonesia experienced a significant increase each year. Even Android users in Indonesia are in the top five active users in the world. There are 47 million, or around $14 \%$ of all cellphone users. Therefore, the introduction of culture for children is very well implemented with collaboration from Android devices, because Android users among students are also very high.

\subsection{Unity 3D}

Unity $3 \mathrm{D}$ is a program for creating games that are designed to be easy for beginners to use. This program is very popular and is the choice of more than 800,000 game creators from all over the world because Unity provides all the core functionality needed to create great games. Unity has high optimization graphics performance and also Unity provides game development features on various platforms, namely Unity Web, Windows, Mac, Android, iOS, Xbox, Playstation 3 and Wii. Unity provides various programming language options for developing games, including JavaScript, C\#, and BooScript. Even though three programming languages are available, most developers use JavaScript and C\# as the language used to develop games(Rahim, 2016). 


\subsection{Coding}

Writing program code is making translation of system weaknesses that have been made in the form of commands that use computers by using programming languages. This stage is a real stage in a system. The programming language systems used are Javascript and C \# with the help of the Unity 3D game engine(Rahim, 2016).

\subsection{Testing} gradual implementation so that it is not focused on certain stages. The stages of the waterfall method are as followsin figure 1:

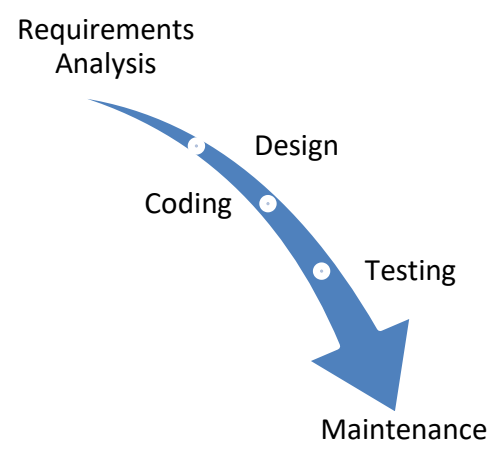

Figure 1. Waterfall Method Steps

\subsection{Requirements Analysis}

The needs analysis phase is done by analyzing user needs, analysis of software and hardware needed in system development and other needs. Making thisgame using the ASUS X454Y PC with AMD Quad-Core processor specifications, 4 GB of memory. The smartphone used to test is XiomiRedmi 4A, Android 7.1.2 N2G47H (Nougat) with 2 GB of RAM.

\subsection{Design}

The purpose of this stage is to provide an overview of what will be done and graphical user interface. This stage fulfills all the needs of users according to the results analyzed such as the display design of development game and helps define the overall system architecture. Documentation produced from this system design stage includes the design of the Application Flowchart, Use Case Diagrams, and the design of the user interface.
Testing is used to ensure that the software created is in accordance with the design and that all functions can be used properly without any errors. This study uses the Blackbox Testing method.

Blackbox Testing is a software testing technique that focuses on the functional specifications of the software. Blackbox Testing works by ignoring the control structure so that its attention is focused on domain information. Blackbox Testing allows software developers to create a set of input conditions that will train all the functional requirements of a program. The advantages of using the Blackbox Testing method are: (1) Testers do not need to have knowledge of a particular programming language; (2) Testing is carried out from the user's perspective, this help to reveal ambiguity or inconsistencies in the requirement's specification; (3) The programmer and tester are both interdependent (Jaya, 2018).

The final stage of system development in the Waterfall model is maintenance which includes the installation and process of system improvement.The maintenance accordance with the wishes of the user or in accordance with the work contract.

\section{RESULT AND DISCUSSION}

The game design must first draw a whole system flowchart so that the game system to be made clearer and structured. A flowchart is a chart that shows a logical flow in a program or system procedure. Flowcharts are used primarily for communication aids and for documentation.

Flowchart used is a type of Flowchart System, which is a chart that shows the workflow or what is being done in the system as a whole and explains the

\subsection{Maintenance}




\subsection{Designing User Interface}

game flowchart is shown infigure 2 below:

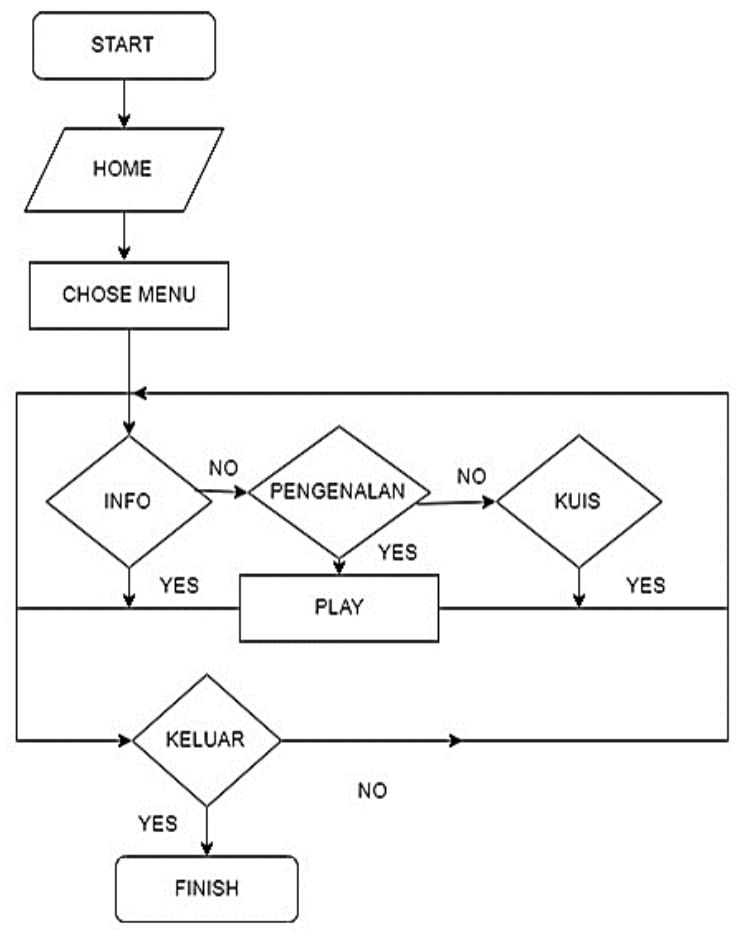

Figure 2. Flowchart of The Game

The flow of game usage can be known through the Use Case Diagram. Use Case Diagrams describe an interaction between one or more actors with the information system to be created. The following is the design of the processes contained in the educational game introduction to traditional musical instruments, illustrated by the Use Case Diagram which can be seen in figure 3 below:

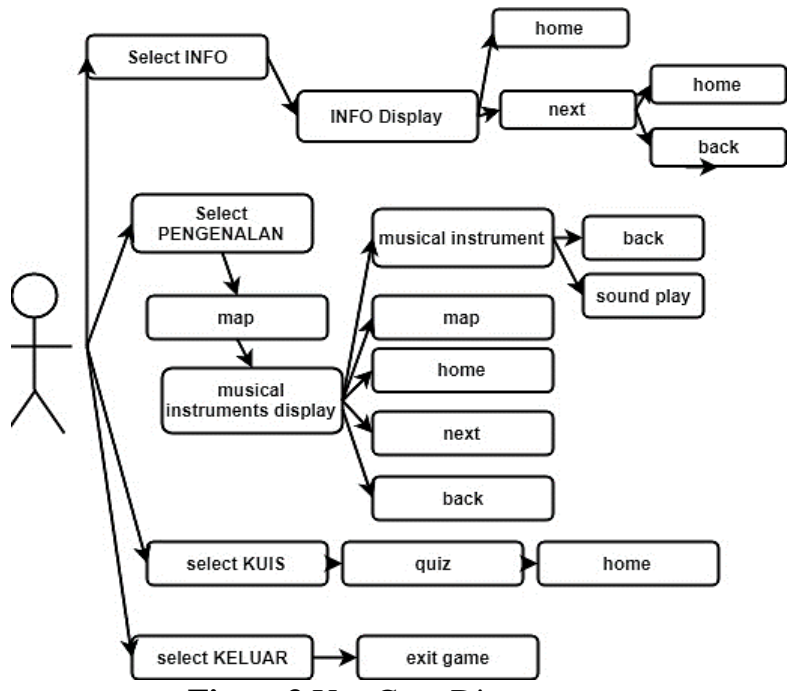

Figure3.Use Case Diagram
As a design product, educational games adapt general design principles which include: proportion principle, emphasis principle, balance principle, rhythm principle, harmony principle and unity principle. A good educational game must meet these design principles in user interface design (Wandah and Rahina, 2018).

The user interface is a set of tools/elements used to manipulate digital objects (Wandah and Rahina, 2018). Rauschenberger et al in (Wandah and Rahina, 2018)stated that a user interface is considered good if it can function well, not only considering the aesthetic aspects. In other words, in determining the form of interface design (user interface), not only visual aesthetic aspects are needed, but also must consider the functional aspects of the elements in the interface design.

In making this user interface of the educational game was using the Draw I/O application that can be accessed offline by installing the application and online through the website. The design prioritizes learning medium that clear and easy to understand. The following is an educational game user interface design for the introduction of traditional Indonesian musical instruments infigure 4 to figure 9:

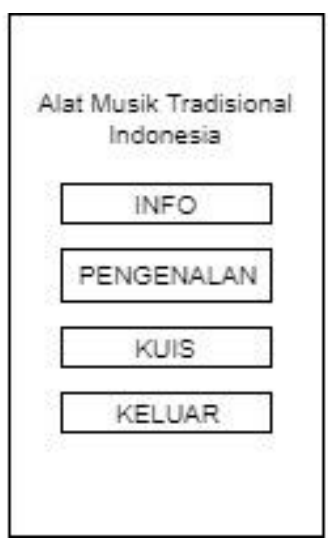

Figure4.Design User Interface of Main Menu Page

The earliest menu is the main menu or home menu which consists of 3 menus and 1 button includingINFO Menu (Information),PENGENALAN Menu (Introduction), KUIS Menu (Quiz) and exit button. 


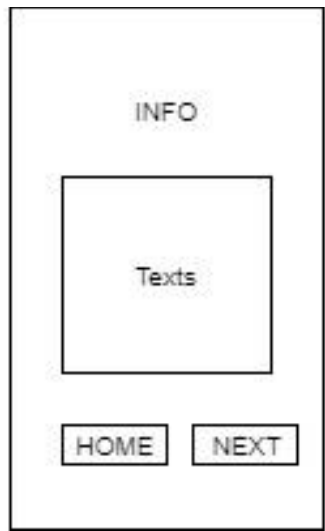

Figure5.Design User Interface of Info Menu Page

The Info menu consists of 2 pages there is introductory page andapplication developer list page.

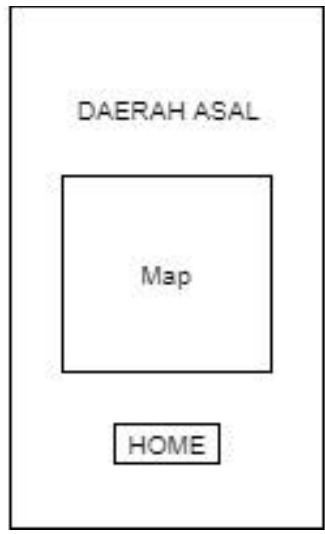

Figure6.Design User Interface of Pengenalan (Introduction) Menu Page

The introduction menu consists of three main pages, namely the Indonesia map page, the instrument listing page, the instrument introduction page. The map page is made so that users can simultaneously learn and visualize regions in Indonesia. The map is divided into 7 main islands namely Sumatra, Java, Kalimantan, Sulawesi, Maluku, Bali, Nusa Tenggara and Papua. The introduction page of musical instruments is equipped with the sound of musical instruments that can be played directly so as to increase user knowledge.

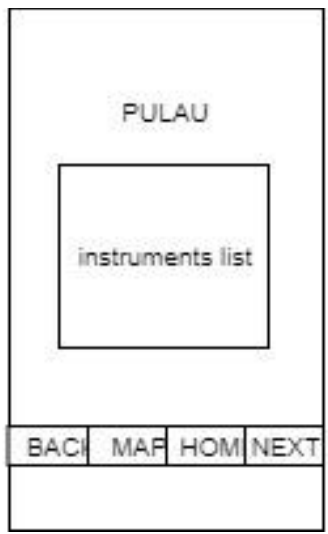

Figure7.Design User Interface Instruments list in Pengenalan (Introduction) Menu Page

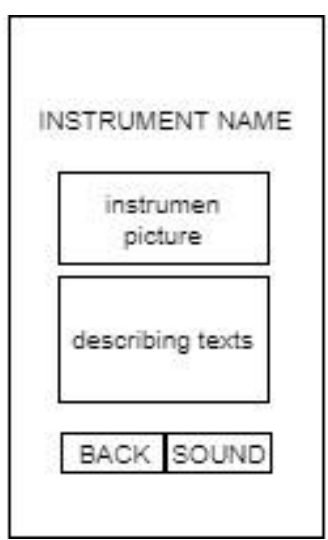

Figure8.Design User Interface Instrument Explanationin Pengenalan (Introduction) Menu Page

The last menu is the QUIZ menu. Quiz made by multiple choice with 4 choices. This is because children prefer to answer multiple-choice questions rather than essay questions. The page is accompanied by a time limit answering each question which is 10 seconds. Questions are also accompanied by a home button to return to the main menu. 


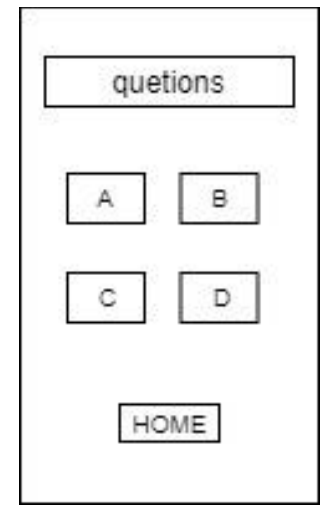

Figure9. User Interface ofKuis Menu Page

\subsection{Design of Game Display}

Display the game created using the Adobe Illustrator CC 2018 application with reference to the user interface that was designed previously. Making the appearance of the game using the main color of brown. In the rules of human and computer interaction, the colors used must not be more than 5 colors. Besides the symbols used must be in accordance with the rules of the use of symbols so that users more easily understand the elements in the game.

Data display on the educational game user interface includes the use of colors, typography, illustrations, and layout/ composition. Typographic analysis is done by examining the type and size of the letters used, setting/ setting letters, giving effects, and the end result on the ease of text to read(Wandah and Rahina, 2018). Below are the results of the game interface display designin figure 10 to figure 15 :

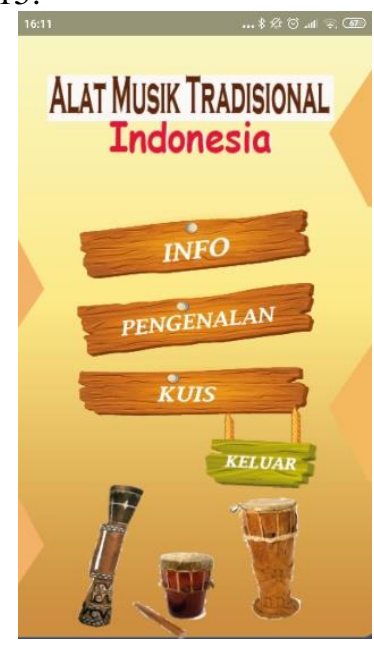

Figure10.Display of Main Menu/Home

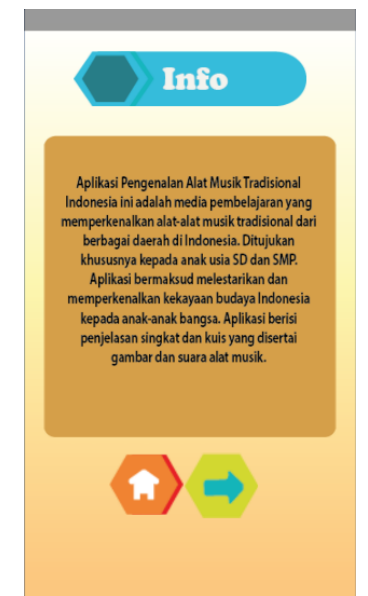

Figure11.Display of Info Menu

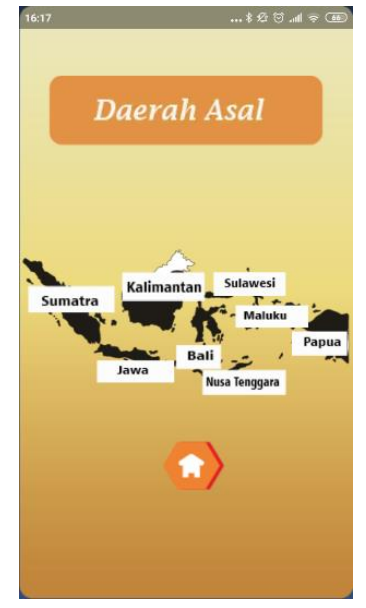

Figure12.Display ofMap PageinPengenalan(Introduction) Menu

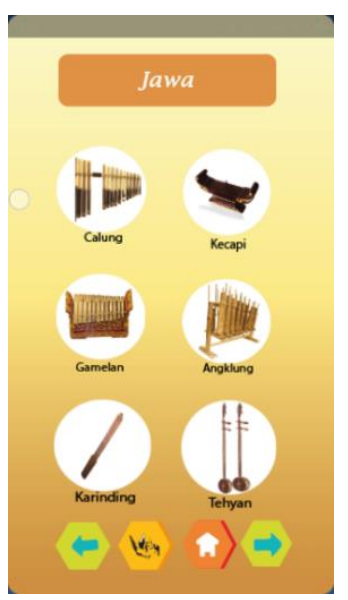

Figure13.Display of Instruments List Page in Pengenalan(Introduction) Menu 
The test results are displayed in table 1 to table 6 below:

Table 1.Main Menu/ Home Testing

\begin{tabular}{llc}
\multicolumn{1}{c}{ BUTTON } & \multicolumn{1}{c}{ FUNCTION } & RESULT \\
\hline Info & $\begin{array}{l}\text { Go to the info } \\
\text { page }\end{array}$ & Success \\
\hline Pengenalan & $\begin{array}{l}\text { Go to the map } \\
\text { page }\end{array}$ & Success \\
\hline Kuis & $\begin{array}{l}\text { Go to the quiz } \\
\text { page }\end{array}$ & Success \\
\hline
\end{tabular}

Table2. Info Menu Testing

\begin{tabular}{|c|c|c|}
\hline BUTTON & FUNCTION & RESULT \\
\hline Home & $\begin{array}{l}\text { Back to the } \\
\text { main menu }\end{array}$ & Success \\
\hline Next & $\begin{array}{l}\text { Go to the next } \\
\text { info page }\end{array}$ & Success \\
\hline Back & $\begin{array}{l}\text { Return to the } \\
\text { first info page }\end{array}$ & Success \\
\hline
\end{tabular}

Table3. Pengenalan (Introduction) Menu Testing

\begin{tabular}{|c|c|c|}
\hline BUTTON & FUNCTION & RESULT \\
\hline Home & $\begin{array}{l}\text { Back to Main } \\
\text { Menu }\end{array}$ & Success \\
\hline $\begin{array}{l}\text { Sumatra } \\
\text { (Talempong, } \\
\text { Saluang, } \\
\text { Hapetan, } \\
\text { Serune, } \\
\text { Kompang, Doll }\end{array}$ & $\begin{array}{l}\text { Return to the list } \\
\text { of musical } \\
\text { instruments from } \\
\text { Sumatra (go to } \\
\text { the instrument } \\
\text { description page) }\end{array}$ & Success \\
\hline $\begin{array}{l}\text { Jawa (Calung, } \\
\text { Gamelan, } \\
\text { Karinding, } \\
\text { Kecapi, } \\
\text { Angklung, } \\
\text { Tehyan) }\end{array}$ & $\begin{array}{l}\text { Return to the list } \\
\text { of musical } \\
\text { instruments from } \\
\text { Java (enter the } \\
\text { instrument } \\
\text { description page) }\end{array}$ & Success \\
\hline $\begin{array}{l}\text { Kalimantan } \\
\text { (Sluding, } \\
\text { Panting, Japen, } \\
\text { Tuma, Sampek, } \\
\text { Japen) }\end{array}$ & $\begin{array}{l}\text { Return to the } \\
\text { Kalimantan music } \\
\text { instrument list } \\
\text { page (go to the } \\
\text { instrument } \\
\text { description page) }\end{array}$ & Success \\
\hline Bali & $\begin{array}{l}\text { Return to the list } \\
\text { of musical } \\
\text { instruments from } \\
\text { Bali (go to the }\end{array}$ & Success \\
\hline
\end{tabular}




\begin{tabular}{|c|c|c|}
\hline BUTTON & FUNCTION & RESULT \\
\hline & $\begin{array}{l}\text { instrument } \\
\text { description page) }\end{array}$ & \\
\hline Nusa Tenggara & $\begin{array}{l}\text { Return to the } \\
\text { Nusa Tenggara } \\
\text { musical } \\
\text { instrument list } \\
\text { page (enter the } \\
\text { instrument } \\
\text { description page) } \\
\text { success }\end{array}$ & Success \\
\hline Maluku & $\begin{array}{l}\text { Return to the list } \\
\text { of musical } \\
\text { instruments from } \\
\text { Maluku (enter the } \\
\text { instrument } \\
\text { description page) }\end{array}$ & Success \\
\hline Sulawesi & $\begin{array}{l}\text { Return to the list } \\
\text { of instruments } \\
\text { from Sulawesi (go } \\
\text { to the instrument } \\
\text { description page) }\end{array}$ & Success \\
\hline Papua & $\begin{array}{l}\text { Return to the list } \\
\text { of instruments } \\
\text { from Papua (enter } \\
\text { the instrument } \\
\text { description page) }\end{array}$ & Success \\
\hline Back & $\begin{array}{l}\text { Go to the } \\
\text { previous page/ list } \\
\text { of musical } \\
\text { instruments }\end{array}$ & Success \\
\hline Map & $\begin{array}{l}\text { Return to the map } \\
\text { page }\end{array}$ & Success \\
\hline
\end{tabular}

Table5.Exit Menu Testing

\begin{tabular}{rrr}
\hline BUTTON & FUNCTION & RESULT \\
\hline Keluar/Exit & Exit from game & Success \\
\hline
\end{tabular}

Table6.Sound Testing

\begin{tabular}{llr}
\hline \multicolumn{1}{c}{ BUTTON } & \multicolumn{1}{c}{ FUNCTION } & RESULT \\
\hline Backsound & $\begin{array}{l}\text { Playing } \\
\text { angklung } \\
\text { sounds during } \\
\text { gameplay }\end{array}$ & \\
& Success \\
Instruments & $\begin{array}{l}\text { Exposes the } \\
\text { Sounds } \text { Success } \\
\text { related } \\
\text { instruments } \\
\text { when clicked }\end{array}$ & \\
\hline
\end{tabular}

Results of the tests that have been done, the application runs as expected with $100 \%$ success results. Where the features and functions of each menu include: INFO, INTRODUCTION, QUIZ, EXIT along with the button inside it to produce the desired output in accordance with the purpose and function of making the application. Display output in accordance with the display design that has been made. The back songs and the sound of the instruments also made the sound as they should. Overall the application is considered feasible to use.

Table4.Kuis Menu Testing

\begin{tabular}{llc}
\hline \multicolumn{1}{c}{ BUTTON } & \multicolumn{1}{c}{ FUNCTION } & RESULT \\
\hline Question & $\begin{array}{l}\text { Quit randomly } \\
\text { every time the } \\
\text { quiz }\end{array}$ & Success \\
\hline $\begin{array}{l}\text { Multiple } \\
\text { Choices }\end{array}$ & $\begin{array}{l}\text { When clicked, } \\
\text { it comes out } \\
\text { true/wrong }\end{array}$ & Success \\
\hline Timer & $\begin{array}{l}\text { The timer } \\
\text { works for } 10\end{array}$ & Success \\
& $\begin{array}{l}\text { seconds } \\
\text { countdown }\end{array}$ & \\
\hline Home & $\begin{array}{l}\text { Return to the } \\
\text { main page }\end{array}$ & Success \\
\hline True/Wrong & $\begin{array}{l}\text { It comes with a } \\
\text { tick/ cross } \\
\text { Sign }\end{array}$ & Success \\
& answer & \\
\end{tabular}

\section{CONCLUSION}

Test results show that the educational game for the introduction of traditional Indonesian musical instruments that have been made functional is running well with the presentation of the test $100 \%$ successful and is considered feasible to use. But the appearance, function, material, and animation still have to be developed to be more leverage when used and effectively provide knowledge.

\section{ACKNOWLEDGMENTS}

Suggestions for further research are to make the quiz menu design more varied, which is to combine and combine multiple questions and choices with text, images, and sound. In addition, you should also test the display and material to the user. 
Journal of the American Chemical Society, 102 (12),

\section{REFERENCES}

Pavithra, A. (2018). Multimedia and Its Applications. International Journal for Research and Development in Technology, 10 (5), 271-276.

Ariffin, M. M., Oxley, A. and Sulaiman, S. (2014). Evaluating Game-based Learning Effectiveness in Higher Education. Procedia-Social and Behavioral Sciences, 123, 20-27.

Barwick, J., Dearnley, J. and Muir, A. (2011). Playing games with cultural heritage: A comparative case study analysis of the current status of digital game preservation. Games and Culture, 6 (4), 373-390.

$\mathrm{Br}$, E. and Ompusunggu, J. (2016). Rancang Bangun Multimedia Interaktif Pembelajaran Alat Musik Tradisional Melayu menggunakan Metode Godfrey.

Dewi, A.R., Isnanto, R.R. and Martono, K.T. (2015). Aplikasi Multimedia sebagai Media Pembelajaran Ilmu Pengetahuan Sosial Materi Budaya di Indonesia menggunakan Unity Engine untuk Sekolah Dasar. Jurnal Teknologi dan Sistem Komputer, 3 (4), 471.

Dian, W.P.A., and Prasita Nugroho, E. .P. (2014). Game Edukasi Berbasis Android Sebagai Media untuk Anak Usia Dini. Jurnal Teknologi Informasi dan Komunikasi, 5 (1), 47-55.

Ginting, S. L. B. and Sofyan, F. (2017). Aplikasi Pengenalan Alat Musik Tradisional Indonesia Menggunakan Metode Based Marker Augmented Reality Berbasis Android. Majalah Ilmiah UNIKOM, 15 (2).

Hssina, B. et al. (2014). Edugame an Android game for teaching children. International Journal of Innovation and Applied Studies, 9 (4), 1531-1540.

Jaya, T.S. (2018). Pengujian Aplikasi dengan Metode Blackbox Testing Boundary Value Analysis (Studi Kasus: Kantor Digital Politeknik Negeri Lampung). Jurnal Informatika Pengembangan IT (JPIT), 3 (2), $45-48$.

Leetian, N. (2013). Designing Mobile Educational Games on Voter"s Education: A Tale of Three Engines. International Journal of e-Education, e-Business, eManagement and e-Learning, 3 (5).

Patil, P.P. and Alvares, R. (2015). Cross-platform Application Development using Unity Game Engine. International Journal of Advance Research in Computer Science and Management Studies, 3 (4), 19.

Rahim, F. (2016). Game Edukasi Pengenalan Alat Musik Tradisional di Indonesia Berbasis Android, Tugas Akhir.

Repository, I. (2011). Institutional Repository Playing games with cultural heritage: a comparative case study analysis of the current status of digital game preservation. This item was submitted to Loughborough's Institutional Repository.

Ribeiro, A.A. et al. (1980). An Approach to the Mapping of Internal Motions in Proteins. Analysis of 13C NMR Relaxation in the Bovine Pancreatic Trypsin Inhibitor.
4040-4051.

Risnawati, Amir, Z., and Sari, N. (2018). The development of learning media based on visual, auditory, and kinesthetic (VAK) approach to facilitate students' mathematical understanding ability. Journal of Physics: Conference Series, 1028 (1).

Šćepanović, S. and Radunović, P. (2015). Game based mobile learning-application development and evaluation. The Sixth International Conference on $e$ Learning, 24-25.

Simkova, M. (2014). Using of Computer Games in Supporting Education, Procedia - Social and Behavioral Sciences, 141, 1224-1227.

Ucus, S. (2015). Elementary School Teachers' Views on Game-based Learning as a Teaching Method. Procedia-Social and Behavioral Sciences, 186, 401409.

Vitianingsih, A.V. (2016). Game Edukasi Sebagai Media Pembelajaran Pendidikan Anak Usia Dini. Inform, 1 (1), 1-8.

Vlachopoulos, D. and Makri, A. (2017). The effect of games and simulations on higher education: a systematic literature review, International Journal of Educational Technology in Higher Education..

Wandah, W. and Rahina, N. (2018). Desain Antarmuka (User Interface) Pada Game Edukasi. Jurnal Imajinasi, 12 (2), 57-64.

Widiastuti, N.I. and Setiawan, I. (2012). Membangun Game Edukasi Sejarah Walisongo. Jurnal Ilmiah Komputer dan Informatika (KOMPUTA), 1 (2), 41-48. 